\title{
Changing Spaces for Civil Society Organisations in China
}

\author{
Berthold Kuhn \\ Department of Political and Social Sciences, Freie Universitat Berlin, Berlin, Germany \\ Email: berthold.kuhn@t-online.de
}

How to cite this paper: Kuhn, B. (2018). Changing Spaces for Civil Society Organisations in China. Open Journal of Political Science, 8, 467-494.

https://doi.org/10.4236/ojps.2018.84030

Received: September 7, 2018

Accepted: October 27, 2018

Published: October 30, 2018

Copyright (C) 2018 by author and Scientific Research Publishing Inc. This work is licensed under the Creative Commons Attribution International License (CC BY 4.0).

http://creativecommons.org/licenses/by/4.0/

\begin{abstract}
Concerns about shrinking spaces for civil society organisations have risen in China over the past years, in particular among international nonprofit organisations. The third sector in China, however, continued its growth in numbers, diversity and activities of organisations, accounting for more than 700,000 registered organisations. Government's financial support to nonprofits significantly increased through contracting out of services. The new Charity Law contains provisions for public fundraising activities, including for online platforms. International activities of Chinese nonprofits took off in the context of participation in global conferences. Chinese NGOs also started to engage in delivering humanitarian aid to communities in other countries. Assessments on shrinking or changing spaces for civil society in China much depend on the type of organisations in focus. This paper pays attention to discourses related to NGO development in China and sheds light on changing spaces for different types of nonprofits in China, those that are negatively affected by new regulations and different kinds of restrictions and those benefiting from emerging opportunities in the context of growing cooperation with the government or the business sector. Analysis based on interviews and talks with experts in China and abroad shows that advocacy-oriented organisations and those receiving foreign funding tend to face more difficulties. Larger international nonprofits with a long track-record in China, however, are seen to continuing or even expanding their activities.
\end{abstract}

\section{Keywords}

Civil Society, Shrinking Space, Changing Space, International NGOs, China

\section{Introduction: Civil Society and Nonprofits in China}

This research is inspired by the overarching question on how to define and con- 
textualise civil society activities in China against the backdrop of both growing opportunities and shrinking spaces for nonprofits. On the one hand many international civil society analysts refer to politically motivated restrictions and seriously curtailed space in China-the monitor of CIVICUS (2017a, 2017b) that tracks conditions for citizen action puts China in the country category of "closed space for civil society". On the other hand we see a continued strong commitment of many Chinese organisations and individuals that engage in mutual and public benefit activities.

The evaluation of restrictions and opportunities for civil society organisations much depends on the type of organisations in focus and the definition of civil society applied to the research agenda. The term "civil society" has been subject to a series of strenuous definitional efforts by academics across the globe (Anheier et al., 2001; Hildermeier, Kocka et al., 2000; Kuhn, 2005/2009; Salomon et al., 1999; Wang, 2011). The normative dimension of the term civil society-in particular the reference to public benefit, policy dialogue and also human rights-has a strong tradition in political and social science research, in particular in Europe. Such normative dimension is usually particularly pronounced when it comes to translate the concept of civil society into the practice of dialogue with Civil Society Organisations (CSOs) or project-based support to non-governmental organisations (NGOs).

The normative dimension of civil society makes the term, however, controversial as any normatively charged definition risks to be viewed as an ideological or politically biased approach to a term. This is a major challenge to the term civil society in the context of international cooperation and explains some of the reservations to it, in particular in countries ruled by ideologically driven one-party regimes like China.

In the context of this research civil society would be defined as.

" $A$ sphere of social organisations and initiatives, separate from the state, the market and the family, that brings people together for diverse forms of social action and interaction, ideally for public or mutual benefit."

In China, it has been possible for researchers to embrace the term civil society for quite some time. Research on civil society and NGOs took off after the Millennium with a series of Institutes established at renowned Universities, including the NGO Research Centre at Tsinghua University renamed Tsinghua University's Institute for Philanthropy in 2015, Center for Civil Society Studies at Peking University, the Institute of Civil Society at Sun Yat-sen University Guangzhou, and Institute of Civil Society Devel-opment at Zhejiang University in Hangzhou.

The academic work on civil society in China was meant to understand the motives, work and social functions of a growing number of privately founded nonprofits that started well targeted initiatives in fields like education and health, cultural exchange, community participation in urban planning, protection of endangered species, pollution monitoring, and also covering support to migrant workers, elderly persons and other marginalised groups such as HIV 
infected persons, drug addicts, victims of domestic violence, prostitutes and street children. A significant number of scholars from China and other countries recognised and analysed the contributions of such organisations to social governance in China (Gao \& Xia, 2016; Gransow, 2004; Huang, 2013; Teets \& Jagusztyn, 2016).

The use of the term civil society (Chinese: gongmin shehui 公民社会) has become politically sensitive after the years 2011/2012. In China, it is now politically more correct to talk about social organisations (Chinese: shehui zuzhi 社会 组织) or the NGOs/NPO sector rather than referring to "civil society". Given the politically motivated reservations on the use of the terms "civil society" in China, this paper operates with various terms. In general, it refers to "civil society" when relating to international discourses and the wider discourse of citizens' engagement. The terms "nonprofits", Non-Govermental Orgaisations (NGOs) or "social organisations" are used when describing specific kinds of organisations and aspects of the operating environment or the work of individual organisations in China. Ding (2008: pp. 212-213) explained why different kinds of terms are used at different times by different people in China. In China, nonprofit organizations (NPOs) are officially called social organizations (shehui zuzhi) or civil organizations (minjian zuzhi) in government policies and documents (Zhu, 2015: p. 2397).

The use of the term civil society has further declined though not ceased to exist in China. ${ }^{1}$ Today, nonprofits or social organisations or more specific terms like philanthropy, charity or social enterprise are predominantly used in China. With regard to legal issues and the work of international nonprofits, the term NGOs (Non-Governmental Organisation) is mostly used.

After more than a decade of growth and expansion of civil society organisations from the 1990s onwards and flourishing academic debates on civil society in China ${ }^{2}$, the term Gongmin shehui (公民社会), or “civil society", has almost disappeared in discourses in China from 2011 onwards. Such development took place in the context of rising criticism on Western ideas and values that would infiltrate and allegedly harm Chinese society. The concept of civil society is one of seven ideas mentioned in the Document Nr. 9. ${ }^{3}$

However, activities of nonprofits were not stalled as a consequence of the rising criticism on civil society discourses. Instead, the discourse focused more on ${ }^{1}$ The term civil society still figures as research areas of institutes and researchers in China, see Institute of Civil Society, Sun Yat-sen University (http://www.chinacsrmap.org/Org_Show_EN.asp?ID=560) and research profile of Prof. WANG Ming of Tsinghua University

(http://www.sppm.tsinghua.edu.cn/english/faculty/fulltime/26efe4891f406f6b011f644d4d2d0093.ht $\underline{\mathrm{ml}}$.

${ }^{2} \mathrm{Ma}$ (1994) concluded in an article in The China Quarterly in 1994 that "Since 1986, there has been a theoretical discourse of civil society in China".

${ }^{3}$ Document Number 9 is a confidential internal document drafted in 2012 and widely circulated within the Communist Party of China by the General Office of the Communist Party of China. The document was not made available to public by the Chinese government, but in July 2013 was allegedly leaked by Chinese dissident journalist Gao Yu. 
specific terms and types of organisations, such as social enterprises, charities and philanthropy. For some nonprofits, regulations for registration have even been eased in 2013 and cooperation and funding opportunities with government agencies at different levels have been substantially increased. Others, in particular advocacy-oriented organisations with a rights-based approach and those relying on foreign funding have come under stronger scrutiny with the purpose to limiting their scope of action and their access to international funding support.

We currently witness controversial discussions on the state and freedom of civil society in China, in and outside the country. Questions related to shrinking, enlarging or changing space for civil society and nonprofits in China were discussed at sessions of the International Society for Third Sector Research (ISTR) conference in Amsterdam in July 2018. Shen (2018) with reference to data analysis from the China Central Finance Project-the project covers 1626 nonprofits that received project funding from government sources-pointed out that increased government funding to those nonprofits had a crowding-in effect for private sector support to those organisations. Zhu (2018) emphasised the role of non-profit support organisations (NSO) in promoting local nonprofits and their cooperation with local government. Nonetheless, he acknowledged that local government policies would vary greatly across locations. Gasemyr (2018) referred to the lack of public trust on nonprofits in China due to still very limited exposure to modern nonprofits but also related to a series of smaller and bigger scandals, such as the Guo Mei Mei scandal that struck the Chinese Red Cross in 2011. However, the 2014 China national survey on inequality and distributive justice also showed that younger and well educated people were more open to value the role of nonprofits. Gasemyr further emphasised the relevance of the evolution of the welfare state for nonprofit development in China and pointed to elderly care as an area where nonprofit activities would be largely welcomed by the government. Levy (2018) referred to the allegedly vague and unclear regulations and the far reaching supervisory functions of public authorities in the context of new legislation in China, in particular to the Ministry of Public Security in the case of the Law on the Administration of Overseas NGOs and the Ministry of Civil Affairs in the case of the Charity Law. Approaching the issue from a different angle, Jia (2018) forwarded the argument that legal legitimacy could create trust and space for nonprofits. Sidel (2018) stressed upon the guo jia an wei (国家安危, national security) debate in China that would mirror the worries of security intellectuals and their concern about unregulated activities of private organisations, in particular those receiving foreign funding. He concluded, however, that referring to "closing spaces" for civil society in China would be overstating and simplifying. Sophisticated governments such as the Chinese government would "mould" third sector governance rather than "closing space across the board."

The purpose of this paper is to engage in reflections on current discourses re- 
lated to civil society in China and to shed light on shrinking spaces and emerging opportunities for civil society and nonprofits in mainland China. More specifically, this paper will seek to answer two questions:

1) What type of organisations, thematic areas, issues and work methods are most affected by restrictions that were imposed in the past years?

2) What type of organisations, thematic areas, issues and work methods benefit most from emerging opportunities?

International scholars largely agree that the take-over of $\mathrm{Xi}$ Jinping led to a more pronounced authoritarian rule in China (Heilmann \& Stepan, 2016) and tightened supervision of academics. However, this research will deliberately not simply equate the take-over of the $\mathrm{Xi}-\mathrm{Li}$ administration in the year 2013 with more restrictive policies towards nonprofits. Unlike in electoral democracies with pronounced party political rivalry-in particular in the United States-Chinese leadership stresses continuity rather than radical change in policy-making.

With regard to the freedom of civil society, some developments in the area of nonprofit supervision and administration in the last years of the Hu-Wen administration (2002-2012), in particular at the subnational level and most pronounced in Shenzhen, might have suggested some significant ease of restrictions for certain types of nonprofits. However, other developments at the international and national level before the take-over of the $\mathrm{Xi}-\mathrm{Li}$ administration already indicated a stricter government response to advocacy type of nonprofit activities while the trend of growing government funding for service delivery by nonprofits already started years before $\mathrm{Xi}$ and Li took over. In her profound analysis of the legal framework for civil society in China, Simon (2013) calls the year 2011, a "remarkable year!" and dedicated one chapter to the political developments in China and at international level, and more specifically to the fund-raising scandals and government responses that affected the nonprofit sector in China in 2011 and the implications of the Arab spring movement with its revolutionary wave of both violent and non-violent demonstrations, protests and riots that started on 18 December 2010 in Tunisia.

The complexity of the subject matter makes triangulation the method of choice. Triangulation refers to the application and combination of several research methods in the study of the same phenomenon, in our case the changing space for civil society organisations in China. Information was collected through literature review, participation in conferences, interviews and talks with experts, in and outside China. We can find a good number of journal articles and book chapters on civil society and nonprofits in China. However, the many changes that took place in the field of legislation and management of nonprofits in China in the past years, pose a challenge to academic publications on the subject matter, in particular for book publications and papers going through peer reviews that take up several months. Thus, talks with experts were important to understand the impact of the most recent policy changes and regulations. Internet based reports, in particular those published by the website China Development 
Brief (e.g. China Development Brief, 2015) and China File (e.g. China File, 2017), were another valuable source of information. Personal talks and semi-structured interviews with civil society organisations and academic experts during several stays in China, in particular in September and October 2017, and in March 2018 and participation in the ISTR world conference in Amsterdam (July 9-12, 2018) complemented the gathering of information and analysis.

This paper will embark on its analysis by first taking a closer look at the global debate on shrinking and changing spaces for civil society. It will refer to policy documents, publications and programmes of major drivers of the critical discourses on space for nonprofits in China, covering in particular institutions of the European Union and German political foundations that are among the frontrunners of the shrinking space discourse (Section 2). The paper will subsequently summarize and briefly discuss the current operating environment of civil society and nonprofits and the recent overhaul of China's legal and regulatory framework governing the work of nonprofits, in particular international NGOs (Section 3). The assessment of changing spaces for civil society in China (Section 4) will refer to overall observations in the context of talks with staff of nonprofits and academics in China in the past two years and specifically comment on types of organisations that might be negatively or positively affected by the legal and administrative overhaul of NGO supervision in China: Subsequently, the paper will present brief case studies of international NGOs based on individual interviews and talks (WWF, SCF and AF). The concluding section will discuss the case of civil society activism in mainland China against the backdrop of global discourses on shrinking or changing spaces and reduction of international aid to local civil society organisations. It will point out that there is plenty of evidence for continued engagement of Chinese organisations and citizens in public and mutual benefit activities, in particular outside the rights and advocacy based dimensions that shape the understanding of the concept of civil society in Western media and by Western think tanks but have never been key features of civil society in modern China.

\section{The Debate on Shrinking or Changing Spaces for Civil Society}

\subsection{From the Heydays of Global Civil Society to Shrinking Spaces Discourses}

\subsubsection{Towards the Heydays of Civil Society}

The heydays of public attention to civil society activism set in after the end of the collapse of authoritarian regimes in Eastern Europe and other parts of the world and lasted until about the time around 2012/2013 when it became evident that the Arab spring movement would not result in a new wave of democratisation, at least not in a short-term perspective.

However, next to the political dimension of civil society activism there were a number of other important factors that had contributed to the growing enthu- 
siasm of civil society activism and research on it, including initiatives of nonprofits to raising awareness on pollution and climate change, the rise of the human rights movement in the years after the end of the Cold War leading i.e. to the establishment of the International Criminal Court by a coalition of NGOs, the increasing support nonprofits received from development agencies for providing social services to vulnerable communities and groups, and the continued contributions of nonprofits to relief and rehabilitation work in the context of major disasters (e.g. the disastrous Tsunami in South East Asia in December 2004 and the major earthquake in Sichuan China in May 2008).

The involvement of civil society organisations in development cooperation and global summits has significantly grown in the past decades. The United Nations, the World Bank the European Commission and many donor agencies put a lot of emphasis on multi-stakeholder dialogues and involvement of nonprofits in programme implementation (Kuhn, 2005/2009). International NGOs extended their fundraising base and got significant attention from the media, in particular in Western countries. The European Commission launched a series of thematic instruments, e.g. European Instrument for Democracy and Human Rights and Civil Society Local Authorities and channelled funds directly to civil society organisations.

The years from 2001 to 2012 when the Global Civil Society Yearbook was published by the Department of International Development of the London School of Economics and Political Science, somewhat marked the peak period of enthusiasm for global civil society activism and research. By this time, a number of civil society and NGO research institutes were founded in China, too, including the NGO Research Centre at Tsinghua University that had started its work in 1998.

The growing support to civil society development and nonprofits by international donors and, in some cases, wealthy business people, was met with enthusiasm by proponents of liberal democracy, in particular those in favour of regime change. Civil society uprising in Ukraine and the Arab spring movement nourished the hope that a growing and assertive civil society movement would ultimately prepare the ground for a transition to a Western-style democracy. Regarding the case of China, Frolic (1997: p. 46) confessed that "our interest in civil society was heightened by two events: The first was Tiananmen... a second event was the end of communism in Eastern Europe". Frolic's statement-by highlighting political events and developments-supports the argument that Western scholars tend to have a strongly normatively charged and politically influenced concept of civil society which in turns explains the difficulties of China's political leadership and scholars to integrate the concept of civil society into national political discourses.

\subsubsection{Rising Concerns on Shrinking Spaces}

The global civil society community has become stronger over a prolonged period of time and has enjoyed high political and social attention as well as growing at- 
tention by researchers over many years. Participation in the global conferences of the International Society for Third Sector Research (ISTR), founded in 1993/1993, has grown over the years and Voluntas, the International Journal of Voluntary and Nonprofit Organisations, has significantly expanded in terms of number of articles per annum. ${ }^{4}$

The growing support and enthusiasm for civil society, in particular support to human rights and advocacy work of nonprofits, has increasingly been perceived as interference in internal affairs by many authoritarian regimes. Assertive and advocacy-oriented organisations had gained political influence and challenged policies and programmes designed by governments at different levels. When some governments responded with imposing restrictions on the further evolution of independent civil society, the international donor community, liberal media and research institutes responded swiftly. China's new authoritarian drive under Xi Jinping and the enactment of a series of security laws, including the one on administration of foreign NGOs in China, raised concerns on shrinking spaces for civil society in China. International media and human rights organisations but also diplomatic missions voiced their strong concern and criticism. Such concerns were amplified by developments in other countries and regions and reports highlighting. In the years 2014 and 2015 only, governments around the world adopted made 96 laws which in the opinion of CIVICUS (2017a) imposed additional restrictions and reduced space for the civil society. Such new restrictions in a significant number of countries included new security laws and regulations, burdensome administrative requirements for registration or re-registration and internal governance of nonprofits, bans or limitations on certain activities, restrictions or tight supervision of international or nation-wide networking, advocacy and campaign style activities, prohibition or strictly limited public fundraising regulations, unfavourable tax regulations, limitations on foreign funding, lengthy approval procedures for work plans or activities involving foreign partners, mandatory affiliations to government agencies or party units and burdensome reporting requirements by government agencies or departments.

Research Institutes and media identified "a trend that is manifold and covers all world regions and regime types." (Wolff \& Oppe/PRI, 2015). Carothers \& Brechenmacher (2014) point out that the intro-duction of restrictive practices in one country could serve as models for other countries. The perceived shrinking spaces for civil society in many countries provoked strong reactions by international organisations, Embassies ${ }^{5}$, the media and such networks and institutions that are particularly concerned with freedom of expression and a favourable political environment for CSO activities.

Among the drivers of the shrinking or closing space discourses are not only

\footnotetext{
${ }^{4}$ Voluntas was founded in 1990 with two issues per year than moving to three, then to four. Now Voluntas publishes six issues per year. Conference participation increased over the years (see International Society for Third Sector Research, https://www.istr.org/default.aspx).

${ }^{5}$ German Ambassador Michael Clauss sent an official letter asking for explanations and clarifications from the Chinese government on the new law governing foreign NGOs in China that would affect the work of German political foundations.
} 
academics, research networks and media even though they initially played an important role, and in the case of some Universities, went out of their way to stand up and march for the freedom of independent research and analysis. ${ }^{6}$ At international level, the institutions of the European Union were strong drivers of the shrinking space discourses, in Europe, both at EU level (focusing on the case of European Central University in Hungary) and in political diplomacy activities in third countries. During the 35th round of the EU-China Human Rights Dialogue which was held in Brussels on 22-23 June 2017, the European Union emphasised the deteriorating situation for civil and political rights in China, which has been accompanied by the detention and conviction of a significant number of Chinese human rights defenders and lawyers. Restrictions on the freedom of expression in China, and systemic issues in the criminal justice system, including cases of arbitrary detention and allegations of torture, were also raised by the European Union

In an effort to analyse the situation in China and to develop a strategy for engagement with civil society in China, the European Commission launched the EU Country Roadmap Facility (RMF) for engagement with Civil Society in China in October 2017. The political sensitivity of the issue, diverging interpretations of the Terms of Reference and limited operational flexibility due to standardised methodologies described by the global RMF project, however, overshadowed this initiatives meant to developing EU strategies for engagement with CSOs in China.

At the political level, the EU demonstrated its strong reaction to the new law on the management of foreign nonprofits in China. Such reaction was a result of pressure from European civil society, in particular from the political wings of European civil society, notably advocacy oriented organisations and Germany's diplomatically powerful political foundations which all have offices in China. The European Parliament (EUP) included freedom for civil society organisations in its many concerns on human rights violations in China and paid explicit reference to China in its report on "Shrinking Space for Civil Society. The EU Response (European Parliament, 2017: pp. 10-14). According to the views of some interviewed Chinese experts, the EUP played the role of exonerating EU member states to take up such sensitive manners in bilateral talks with China. Furthermore, China's diplomatic charm offensive in Eastern Europe is seen as challenging EU Cohesion and further deteriorated EU-China relations. ${ }^{7}$

A series of conferences and publications have been devoted to the shrinking space issue in EU member states, in particular in Germany, and worldwide. The German Institute for Area Studies which publishes the Journal of Current Chinese Affairs organised a discussion on "Shrinking Spaces for NGOs: How Should

\footnotetext{
${ }^{6}$ The March for Science was launched in 2016 and unites more than one million individual advocates, thousands of community organizers, and hundreds of partner organizations, in particular Universities. The case of Cambridge University press, discussed in this paper, was frequently quoted as an example of University action eventually upholding the principle of academic freedom.

${ }^{7}$ Talks with a Member of the European Parliament on 30 April 2018 in Berlin.
} 
We Deal with the Rise of Authoritarian Practices?" and specifically referred to "civil society in authoritarian regimes such as Cambodia, China, Egypt, Russia, and Uganda" but also to authoritarian practices in formally democratic countries such as Ecuador, Hungary, and Israel. ${ }^{8}$ The renowned civil society advocacy group CIVICUS published a Map on Spaces for Civil Society-the Civil Society Monitor Project ${ }^{9}$ - in which space for civil society in China is labelled "closed" ranking even lower than Russia ("repressed"). The Heinrich Boell Foundation, affiliated to the Green Party in Germany, echoed the critical analysis in a conference publication (Unmuessig, 2016) ${ }^{10}$ quoting a statement on China that reads "schärfer als unter Putin: China misstraut NGOs" ("more serious than Putin: China mistrusts NGOs"). For some, China's political system figures as a leading example for curtailing the freedom of NGOs, in other reports China would figures as one of the less dramatic cases and be referred to as a country where "burdensome registration procedures" prevent the further development of civil society (Wolff \& Oppe/PRI, 2015: p. 1). If compared to Western liberal democracies, the laws and regulations in China exhibit a series of restrictions. Nonprofits face close monitoring and supervision by the government. Public fundraising is restricted to designated organisations and registered charities. However, the dynamic economic development, the pressing need for pollution monitoring and the many social challenges also provide a plethora of opportunities for nonprofits in China.

In academia, the conflict between Cambridge University Press and Chinese authorities over online content made headlines. ${ }^{11}$ The movement of shrinking space for civil society gained additional momentum because it is discussed in the context of wider foreign policy issues and considered to be part of a larger movement against restrictions imposed by authoritarian leadership on freedom of science, freedom of expression and assembly.

Democracy and governance index projects criticize the situation in China in a rather drastic way. Freedom House Index (2018) and Bertelsmann Transformation Index (2018a) are amongst the most renowned index projects. Both are produced by two prominent Western think tanks and have been criticized for their normative bias in providing comparative country assessments on democracy and governance issues. However, they are still relatively widely used by academics, practitioners and media (Kuhn, 2011). Freedom House, a US American think tank, classifies China as "not free" and attributes the low ranking of 6.5 to it, the same as Russia. Only few countries rank lower.

"China's authoritarian regime has become increasingly repressive in recent ${ }^{8}$ GIGA (2017)

https://www.giga-hamburg.de/de/event/shrinking-spaces-for-ngos-how-to-deal-with-the-rise-of-aut horitarian-practices

${ }^{9}$ Civicus (2017): Civil Society Monitor, https://monitor.civicus.org/ see also Fioramonti (2012).

${ }^{10}$ Unmuessig (2016): Zivilgesellschaft unter Druck—shrinking—closing—no space, Conference Publication of Heinrich Boell Foundation, Berlin, May 2016.

${ }^{11}$ Guardian (Kennedy \& Phillips, 2017): Cambridge University Press Backs Down Over China Censorships. 
years. The ruling Chinese Communist Party (CCP) is tightening its control over the media, online speech, religious groups, and civil society associations." (Freedom House, 2018).

Bertelsmann Transformation Index (2018b) ranks China slightly higher (status index $5.02,81^{\text {st }}$; place governance index $4.71,79^{\text {th }}$ place) in the list of all observed countries but below Russia.

BTI attributes 2 points to category "association and assembly rights" in 2018, maintaining the same level of assessment level since 2006. The section on civil society reads:

"The number of registered civil society organizations in China has increased from 153,322 (2000) to 662,425 (2015), but these organizations are not allowed to operate independently, instead, they need to find a governmental host organization and then subject themselves to demanding procedures to obtain registration with the Ministry of Civil Affairs or its local counterparts. This severely restricts their autonomy" (BTI China 2018).

The Rule of Law Index produced by the World Justice Project (2018) also attributes very low scores to China in the category "fundamental rights" (factor score 0.31 and global rank 108 out of 113 countries) and the sub-category "freedom of association" (factor score 0.18 ).

The rights perspective is dominant in all of the above mentioned index projects. This could be explained by the fact that it is more difficult to capture opportunities than restrictions. Thus, evaluations of China on space for civil society are very critical even though the number, capacity and diversity of nonprofit organisations is still growing.

\subsection{New Perspectives on Civil Society Discourses}

The Maecenata Institute for Philanthropy and Civil Society in Berlin aimed at adopting a new perspective on the shrinking space debate and organised a symposium on "The Changing Space for Civil Society"12 taking into consideration contrasting developments in a number of countries and regions (Strachwitz, $2017)^{13}$. Alscher \& Priller (2017) stated that "the diagnosis of a "Shrinking Space" fails to consider the complete picture by concentrating mainly on legal changes, and thus perceiving civil society as a plaything at the hands of the state. This perspective neglects the autonomy of civil society as an independent and distinct

${ }^{12}$ The symposium took place on October 17, 2017 in Berlin and marked the 20 anniversary of the Institute. For the report see: Hummel \& Kreutzer (2017); Maecenata Institut für Philanthropie und Zivilgesellschaft (Ed.): The Changing Space for Civil Society: ein Symposium in Berlin am 17. Oktober 2017. Berlin, 2017 (Europa Bottom-Up 20).

http://nbnresolving.de/urn:nbn:de:0168-ssoar-55079-0

${ }^{13}$ Strachwitz, Rupert Graf 2017. Shrinking or Changing? in: Maecenata Institut für Philanthropie und Zivilgesellschaft (Ed.): The Space for Civil Society: Shrinking? Growing? Changing? Berlin, 2017 (Opuscula 104), pp. 5-10.

${ }^{14}$ Alscher \& Priller (2017). The Changing Social Fabric, in: Maecenata Institut für Philanthropie und Zivilgesellschaft (Ed.): The Space for Civil Society: Shrinking? Growing? Changing? Berlin, 2017 (Opuscula 104), pp. 11-15.

http://nbn-resolving.de/urn:nbn:de:0168-ssoar-54028-9 
sphere of society. ${ }^{14}$ Strachwitz (2017: p. 8) reminded us that "Finally, it seems necessary to look at the relationship between civil society and the arena of the market, a sphere of public life the importance and sheer size of which has grown beyond all expectations since the failure of the state-run economies." The European Foundation Centre shared this view. Civil Society is facing a number of challenges but also opportunities. The popular talk of a "Shrinking Space for Civil Society" is not the complete story (European Foundation Centre, 2017). ${ }^{15}$

Furthermore, the changing space discourse may also better reflect developments in the context of aid reduction discussed in the Voluntas April 2018 issue (Appe \& Pallas, 2018). In the case of China, we definitely see a reduction of foreign aid to nonprofits and such reduction is not only due to stricter regulations but also to changing donor policies in the context of China's middle income status.

The impact of policies targeting the operation of civil society organizations seems much more differentiated than one would probably presume when looking at restrictive laws and government regulations, in particular in China. Some legislative or regulatory provisions that would not meet certain criteria typically viewed as encouraging nonprofits might have positive effects. In China, the Regulation on Administration of Foundations was promulgated by the Ministry of Civil Affairs in 2004 and the foundation sector experienced rapid growth in China even though these regulations contained some clauses that were seen as not going very far in promoting the establishment of nation-wide operating foundations, e.g. requiring a high capital investment for national level foundations and also not being pronounced in protecting the will of the founder. However, today these regulations are regarded as a major break-through for the establishment of independent private foundations active in the field of education, cultural exchange, science, environmental protection and other areas. ${ }^{16}$ In 2011, the number of private foundations already exceeded 1000 and climbed to over 6300 foundations by 2017 (Council on Foundations, 2017). The regulations are currently under revision but no one would expect that the revised regulations would seriously hinder the work of private independent foundations. Meanwhile, a significant number of foundations have been established in China, many by famous industrial groups or business people. Saich (2018) referred to new opportunities for nonprofits in China:

"China is much more affluent now. And particularly a lot of young people begin to not only be interested in making money, making wealth, but they've also become much more interested in the environment in which they live. Not just the physical environment, but the social environment as well."

Such a "changing space" perspective would also have to take a closer look at

${ }^{15}$ European Foundation Centre (2017). Announcement of the above mentioned Symposium on The Changing Space for Civil Society" http://www.efc.be/event/the-changing-space-for-civil-society/

${ }^{16}$ At the global ISTR conference in Amsterdam in July 2018, researchers from China and other countries discussed the impact of various regulations for nonprofits in China in a controversial way. However, their views largely converged with regard to the positive impact of the foundations regulation of 2004. 
motives for alleged restrictions and not jump to the "shrinking space" conclusion. It would need to look at the legitimacy, wording and the actual impact of restrictions in view of tightened public security, activities of terrorist and militant organisations and politization of civil society.

Looking at China, Hildebrandt (2016) argued that "we need to set aside problematic assumptions about the goal and intentions of CSOs... civil society literature predicts that the rise of the third sector will serve as an antagonistic and politically destabilizing force against authoritarian regimes (p. 125).”

China recognizes the importance of a reliable legal system even though it shows concern over political assertion of lawyers. At the occasion of the "Hundred Jurists and Hundred Lectures" meeting, China's Supreme People's Court Deputy Secretary Jiang Bixin delivered a speech on "Implementing the Rule of Law for Guaranteeing the Five Development Concepts." He explained that economic and social development cannot take place in the absence of the rule of law, and further stated that the current problems arising in China's development are directly linked to the rule of law's incomplete development (Gitter, 2016). The official discourse pays much attention to the rule of law or rule by law. The new overseas law is also presented as an orderly way to welcome and govern foreign NGOs in China.

There is a considerable variety of spaces and opportunities. China's policy style is characterised by local experimentations. This does not only apply to economic but also social policies. Simon (2013) discussed at length the many different pilot models for NGOs governance in China with particular emphasis on the city of Shenzhen where the term civil society was used in official language and nonprofits enjoyed significant freedom and opportunities. Simon (2013: p. 22) referred to the "Cooperative Agreement on Pushing Forward to Integrated Reforms to Civil Affairs Undertakings" signed by the Shenzhen municipal government with the Ministry of Civil Affairs and stated that "Guangdong in general and especially the Special Economic Zone (SEZ) of Shenzhen, has been quite innovative in civil society development" (Simon, 2013: p. 2077).

In China, top level leadership discourses continue to emphasise the role of nonprofits, referring to the actual and potential contributions of "social organisations". During the opening of the 19th National Congress of the Communist Party of China on 18th October 2017, President Xi mentioned "social organisations" (the most common Chinese term for nonprofits) several times in connection with other topics such as consultative democracy, community governance, environmental governance and party building at the grassroots level, with philanthropy and volunteering also highlighted.

\section{Legal Status and Operating Environment of CSO in China}

\subsection{Legal Basis and Key Regulations on Nonprofits in China}

China's legal and regulatory environment for civil society and nonprofits has

been subject to scrutiny and analysis by many Chinese and foreign experts. The 
most comprehensive analysis - a 500 pages piece of work-was published by the US American legal scholar Karla Simon in $2013^{17}$ and traces the evolution of the legal and regulatory framework back to the traditions and time of imperial China. With regard to contemporary China, much attention is paid to policies for registration of all kinds of nonprofits at national, provincial and city level, including religious organisations. The book presents and discusses various experiments and innovative regulations, e.g. in the city of Shenzhen where nonprofit policies and regulations are considered to be the most liberal. ${ }^{18}$

Comments on the most recent changes of legislative and regulatory provisions could be found on the website of China Development Brief ${ }^{19}$ that is by most China experts regarded as a very reliable and the most widely accessed source of information for civil society development in China.

China is a civil law country. Nonprofits fall into four primary legal categories.

- Social Associations (SAs) (社会团体, shehui tuanti), which are the equivalent of membership associations.

- Non enterprises unions (民办非企业, minban feiqiye); or Social Service Organizations (社会服务机构, shehui fuwu jigou),

- Foundations (基金会, jijinhui); and

- Public Institutions (事业单位, shiye danwei).

While public institutions could not be established by private persons, associations require a relatively high number of individual members (over 50 individual or over 30 institutional members $)^{20}$ and would usually not be the primary choice for project or action oriented nonprofits seeking a significant degree of independence from the government.

Most of the independent nonprofits involved in project work, e.g. in the field of environment, health or social work, would prefer to choose the minban feiqiye status because such organisations could be managed in a more executive style by the leaders of the organisations, not requiring meetings with members of the organisations. Foundations require a relatively high amount of capital and need to serve a specified purpose. Grant-making organisations would typically choose the legal form of a foundation.

Nonprofits required a supervisory government agency prior to file their registration with the Ministry of Civil Affairs until at least 2013. This provision of finding a government agency_called "dual management" or "mother-in-law system" by some-was particularly challenging for smaller organisations as government agencies had seldom an incentive to engage with and supervise the activities of a private independent organisation.

Therefore, a significant number of organisations choose to establish a business rather than to obtain a nonprofit status. This was seen to be a pragmatic way out

\footnotetext{
${ }^{17}$ Simon (2013). Civil Society in Chna. The Legal Framework form ancient times to the "new reform era"-Oxford University Press.

${ }^{18}$ Simon 2013. Developments in Shenzhen (Simon, 2013: p. 277).

${ }^{19} \mathrm{http}: / / \mathrm{www}$. chinadevelopmentbrief.cn/ there is a Chinese and a Emglish version available.

${ }^{20}$ Simon (2013: p. 243).
} 
of a burdensome registration process and even large international nonprofits such as Greenpeace opted for this status and currently still operate on this basis.

As long as tax benefits have not been significant for nonprofits, a registration as business was indeed a somewhat attractive option to ease registration, reduce some administrative requirements and to make it easier to transform the organisation in a truly profit-oriented venture, e.g. a consulting firm. Tax policies are currently changing in the context of the new Charity Law, making it more attractive for nonprofits to obtain such status.

With regard to the number of registered nonprofits, China has experienced a clear and steady growth trend in the past decades. The trend has been most pronounced for minban feiqiye suggesting that the legal status of an organisation run by a CEO was a particularly attractive venture in China. This fact already points to emerging opportunities for nonprofits in China and makes the burdensome registration procedures look less dramatic. Huang Haoming, the former Chief Executive of Chinese Association for NGO Cooperation, once used to compare the growth figures of the Chinese NGO sector with the growth figures of Chinese GDP. Both growth rates would be carefully moderated by the Government, he said at several occasions.

In April 2018, the number of registered organisations amounted to 360,399 associations (shehui tuanti), 416,733 non-commercial enterprises (minban feiqiye) and 6,632 foundations (jijinhui), with the total number amounting to 783,764 nonprofits up from 606,000, equalling 29.3 percent, from December 2014 (Ministry of Civil Affairs, 2018). The growth rate of nonprofits slightly exceeded the GDP growth rate in the past years. They work on a wide range of thematic areas and issues, including education and health, environmental and climate protection, social work and poverty alleviation, and some of them would engage in rights based work, e.g. representing the interest of minorities or migrant workers who have limited opportunities for integration into the formal job market.

Annual donations to charities in China grew from 10 billion to 100 billion yuan in the past decade, but at the same time a number of major scandals occurred in which managers of charities misused funds and the organizations' reputations suffered, causing the public to call for more transparency and tighter management of charities. ${ }^{21}$

\subsection{Recent Legislative and Regulatory Changes}

With regards to the operating environment, two recent legislative changes are having a significant impact on the work of nonprofits in China. These are:

- the passing of the Charity Law in March 2016, which provides certain nonprofits with tax benefits and fundraising opportunities and

- the new Law on the Administration of Overseas NGOs, which came into

${ }^{21}$ Xinhua Insight: Charity Law to Smooth China's Last-Mile Drive to 2020 Targets, Xinhua (2016a); Xinhua Insight: NPC Hopes Charity Law Can Help Poverty Fight, Xinhua (2016b). 
force on January 1, 2017 requires foreign NGOs to identify a Chinese partner organisation and to register with the Ministry of Public Security (MPS) or its provincial-level equivalents before establishing an office within mainland China.

The Charity Law is widely seen as a positive law for the work of domestic NGOs. After more than ten years of discussions and reviews, it became effective on 1 September 2016. The Charity Law's provisions affect not only domestic and foreign nonprofits, but also a wide range of companies and corporate social responsibility initiatives. It includes an expanded definition of "charitable activities," tax incentives for qualifying organizations, new registration procedures, and rules for donation and volunteer management (Ashwin \& Stratford, 2016). As of May 2017, the Ministry of Civil Affairs had accredited 1245 social organizations as charitable organizations. On August 31, MCA released the first batch of approved internet fundraising platforms, including those of Tencent, Taobao, Xinhua, and Baidu. The Ministry of Civil Affairs (MCA) is charged with determining which online platforms can be used for charities to fundraise and can also establish its own platforms. (CDB, April 20, 2017).

A charity does not represent a legal category in its own right. To become a charitable organization, a group must register first as a legal form of NPOs, then apply for charitable accreditation. Article 88 of the 2017 Charity Law states the need to educate a new generation of talents in charity management through tertiary education and research institutions. This should offer opportunities for institutions to develop relevant curricula for academic and vocational training. Many CSOs may see this development as a positive move to the professionalization of their management and operations. Donor agencies and industries may also provide support for this development.

The Law on Overseas NGOs is widely seen as law restricting and strictly regulating the work of foreign and international NGOs. Lang (2018) pointed out that the Chinese government aimed at shrinking grey areas of NGOs through law-making. China Development Brief, in cooperation with the Center for Charity Law of the China Philanthropy Research Institute at Beijing Normal University published a simple guide to "A Simple Guide to the Overseas NGO Law" (CDB, 15. Dec. 2016). Before the law came into existence, few international NGOs were registered with the Ministry of Civil Affairs. ${ }^{22}$ Most operated in a grey area. The new law for overseas NGOs provoked critical diplomatic reactions. It was seen as another restrictive law passed in the context of a series of other laws introduced between 2014 and 2016, including the Counter-terrorism Law, National Security Law, and Cybersecurity Law. The major points of concern relate to the new mandate given to the Ministry of Public Security for closely supervising the activities and the many administrative requirements for planning and implementing activities with Chinese partner organisations. In the

${ }^{22}$ In 2015, only 29 foreign NGOs had registered representative offices with the Ministry of Civil Affairs. http://www.chinafile.com/ngo/latest/fact-sheet-chinas-foreign-ngo-law 
first year after the law came into effect, there was an uncertainty about continuation of activities. However, only few foreign NGOs and foundations suspended their operations. Most international NGOs, including larger ones like World Wide Fund for Nature, Asia Foundation and Save the Children Fund continued their operations with temporary permits and re-registered in about 6 months, many with the Chinese Peoples Association for Friendship with Foreign Countries, one of the organisations that hosts a significant number of international NGOs.

A point of major concern related to both laws is the relatively vague definitions of organisations that would be covered by the new legislation. In early May 2017, the government announced plans to regulate private think tanks by placing them in the same category as not-for-profit social organizations. Previously, there had been no specific regulation for private think tanks and their legal status was unclear. Offices of foreign Universities facilitating exchange and research cooperation in China were not automatically exempted from registration and some need to find new administrative arrangements.

\section{Changing Spaces for Civil Society in China}

\subsection{Overall Observations}

While it has been possible for Chinese researchers to embrace the term civil society for quite some time, the use of the term civil society (Chinese: gongmin shehui 公民社会) has become politically sensitive after the years 2011/2012. In China, it is now politically more correct to talk about social organisations (shehui zuzhi 社会组织) or the NGOs/NPO sector rather than referring to "civil society".

China has tightened supervision and control of nonprofits and cracked down on a number of political dissidents in the past years. However, it would be misleading to speak of a "closed space for civil society" in China as a CIVICUS (2017a) report and others would describe the current situation in China.

Assessments of shrinking or changing spaces for civil society in China much depend on the type of organisations in focus. Brook (1997: p. 25) developed a categorization of civil society organisation based on principles of auto-organisation and selected historical types which has been found useful for analysing shrinking spaces and emerging opportunities of different types of organisation in China, covering those working for pubic as well as mutual benefit purposes. The initial list of categories by Brook (1997)_based on a survey of sources from the sixteenth to the twentieth century-was slightly modified, adding labour rights organisations as a subsection of occupational groups and a new category of organisations driven mainly by solidarity extended to vulnerable groups and communities. Solidarity driven organisations developed in China in the context of the growing rich-poor divide and with the support of international development assistance. The categories are focused on the nature of the activities and, thus, would include local, subnational, national and international organisations. 
Looking first at the different categories of nonprofits presented in Table 1, we would, however, conclude that some, actually most categories of organisations tend to enjoy moderate freedom and growing opportunities. The above given figure with reference to the categories of Brook (1997) provide a first overview of different types of social organisations and their level of freedom in China. The assessment reflects the overall assessment made by observations of the author and expert consultations in the past years, in particular in the years 2016, 2017 and 2018. The situation of individual organisations falling within one category might vary to a significant degree. However, the figure helps us to understand that a broader view on civil society will lead to a quite differentiated analysis showing us a more positive picture of the spaces for civil society in China than we would expect from following the many critical discourses on closed space for civil society in China.

Talks with Chinese NGO experts confirmed that the number of village and neighbourhood associations, trade and professional associations, alumni and expert groups as well as solidarity groups would still grow and only very few of them would meet problems in the process of registration or interaction with the authorities. Given the economic development in China, the rise of the corporate sector and the growing number of rich people, many more organisations are able to tap significant amounts from private sources. However, there are some politically sensitive issues that are considered to challenge the integrity of the state or the party and are strictly monitored by the authorities, in particular the Ministry of Public Security.

Individuals or groups addressing politically sensitive issues relating to the status of Tibet or Xinjiang face serious problems with the authorities. Open support to human rights defenders or challenging the supreme authority of the Chinese Communist Party or its political leaders will also be sanctioned. The authorities are particularly sensitive in cases of open protests, social mobilisation efforts and advocacy work for contentious issues. Those organisations working on labour issues and, in particular those organising labour unrests, face problems. The responses of the authorities, however, vary greatly. Nonprofits engaging in conflicts with authorities or are affiliated to organisers of protest movements may see their registration not extended or face close supervision and unannounced investigations, in particular in the context of party meetings and major international summits. This may even apply to organisations working in sectors which are generally perceived as NGO friendly. At least one such case-a registration of an environmental advocacy organisation could not be extended or renewed-has been reported to the author in the context of talks to many nonprofits in China. Talks with experts, however, confirmed that it would be difficult to establish any rule with regards to responses of the authorities to advocacy or protest activities. Some experts stated that the impact of protests would matter greatly, sometimes more than the content. The more public attention generated, the more serious the consequences for those chiefly involved in it. Such government 
Table 1. What kind of CSOs do we put in focus? Source: own design, partly based on Brook (1997: p. 25).

\begin{tabular}{llll}
\hline $\begin{array}{l}\text { Type of } \\
\text { organisation }\end{array}$ & Examples & $\begin{array}{l}\text { Methods and } \\
\text { Orientation }\end{array}$ & Degree of Freedom and Opportunities \\
\hline $\begin{array}{l}\text { Locality } \\
\text { Groups }\end{array}$ & $\begin{array}{l}\text { village and native-place societies, } \\
\text { neighbourhood associations }\end{array}$ & $\begin{array}{l}\text { networking } \\
\text { mutual benefit purposes }\end{array}$ & $\begin{array}{l}\text { enjoy operational freedom, unless involved } \\
\text { in contentious issues }\end{array}$ \\
$\begin{array}{l}\text { Occupational } \\
\text { Groups }\end{array}$ & $\begin{array}{l}\text { guilds, trade associations, } \\
\text { occupational associations, } \\
\text { labour rights organisations }\end{array}$ & $\begin{array}{l}\text { networking } \\
\text { mutual benefit purposes }\end{array}$ & $\begin{array}{l}\text { enjoy freedom and growing opportunities, } \\
\text { with the exception of labour rights } \\
\text { organisations }\end{array}$ \\
$\begin{array}{l}\text { Spiritual } \\
\text { Fellowships }\end{array}$ & $\begin{array}{l}\text { official religious societies, } \\
\text { temples, philosphers, cults }\end{array}$ & $\begin{array}{l}\text { networking } \\
\text { mutual benefit purposes }\end{array}$ & $\begin{array}{l}\text { official religious societies enjoy moderate } \\
\text { freedom but limited space, cults may face } \\
\text { serious repressions }\end{array}$ \\
$\begin{array}{l}\text { Epistemic } \\
\text { communities }\end{array}$ & $\begin{array}{l}\text { expert networks, academics, } \\
\text { alumni associations }\end{array}$ & $\begin{array}{l}\text { networking, educational purposes, } \\
\text { influencing } \\
\text { mutual and public benefit purposes }\end{array}$ & $\begin{array}{l}\text { enjoy moderate to high freedom (issue } \\
\text { sensitive in academia) and growing } \\
\text { cooperation opportunities with government }\end{array}$ \\
$\begin{array}{l}\text { Solidarity } \\
\text { Groups }\end{array}$ & $\begin{array}{l}\text { social work, support to } \\
\text { vulnerable groups (such } \\
\text { as disabled persons and children), } \\
\text { environmental protection }\end{array}$ & $\begin{array}{l}\text { helping, supporting, empowering } \\
\text { public benefit purposes }\end{array}$ & $\begin{array}{l}\text { enjoy moderate freedom and growing } \\
\text { opportunities, including with private sector; } \\
\text { those addressing rights issues and receiving } \\
\text { foreign funding face shrinking spaces }\end{array}$ \\
$\begin{array}{l}\text { Groups addressing } \\
\text { common causes } \\
\text { and public policy } \\
\text { issues }\end{array}$ & $\begin{array}{l}\text { pollution monitoring, international } \\
\text { friendship societies, policy advocacy } \\
\text { work }\end{array}$ & $\begin{array}{l}\text { awareness raising, enlightening, } \\
\text { networking, shaming, mobilising, } \\
\text { public benefit purposes }\end{array}$ & $\begin{array}{l}\text { freedom and space depend on the focus of } \\
\text { work and contacts to CCP and government, } \\
\text { some enjoy growing opportunities, feminist } \\
\text { action groups face shrinking spaces }\end{array}$ \\
\hline
\end{tabular}

policies rule out the possibility to organise major political or social campaign without the consent of the authorities. Public security is a prime concern of the authorities at all levels of government in China. However, such concern is probably also shared by the majority of Chinese people, many of them still remembering the chaos created by the cultural revolution and deeply concerned about social anarchy. With regard to the work of international NGOs, one of the interviewed experts working for international NGOs in Beijing pointed out that restrictions for foreign NGOs were strongly motivated by nationalist perspectives aiming at reducing the influence of international organisations and developing a civil society with Chinese characteristics.

Tackling the issue of spaces and opportunities from a more political perspective, the selection of categories could be criticized for not assigning a specific category to media or political foundations. The proposed list only mentions "media" and "political foundations" as sub-categories of institutions addressing common causes. According to observations and collected expert opinion, media as well as groups focusing on rights-based issues, such as labour and migration issues, suffer the most from authoritarian policies that aim to censor discourses and curtail freedoms of civil society organisations in China. With regard to censorship of social media content, in particular WeiBo and WeChat content, King-wa Fu (2018) would speak of "control 3.0 policies" that are characterised by a comprehensive set of censorships and control activities that impacts everyday life. In his analysis, he refers to the me-too campaign and content produced by feminist networks that was removed from social media 
platforms. $^{23}$

Political foundations would also suffer from more rigorous scrutiny. Six German political foundations are well established in China. With the exception of the Friedrich Ebert Foundation, they still significant time for re-registration of their offices in China. However, within a period of six month they managed to register the foundations.

Organisations working for the common cause of environmental or climate protection would mostly not suffer from restrictions but rather enjoy more opportunities for engagement, collaboration with government authorities and also receive support from the corporate sector. In sum, the picture of organisations and groups addressing common concerns and public benefit purposes does not look as gloomy as perhaps presented in some shrinking space reports that refer to the case of China as "closed space", such as the CIVICUS (2017a) report.

Chinese authorities demonstrate a high level of sensitivity with regard to issues and activities that relate to global social movements. Blogs and accounts in China, including ATSH, which stands for anti-sexual harassment, and the WeiBo account of Feminist Voices that related to the anti-sexual harassment movement \#Metoo that originated in the USA in the context of the allegations against movie producer Weinstein were soon blocked (The Guardian, 2018). ${ }^{24}$

Given the serious criticism on the Chinese authorities for cracking down on political activists and closing spaces of civil society, there is usually little room to raise awareness on the many activities of civil society in China that address mutual and public benefit purposes in nonprofit structures that are operating largely independent from government or party interference, at least with regard to agenda setting and daily operations. The number of NGOs that have been founded without involvement of government or party authorities is hard to figure out but it is definitely a significant number of organisations and probably far more than half of the newly registered nonprofits according to estimates of interviewed Chinese experts. The number of companies founded without involvement of any government authority, however would be much higher. Government put a credit system for nonprofits in place and the interviewed expert agreed that party membership is definitely considered a plus point for nonprofits. There are also considerations to make party membership of governing body members mandatory for nonprofits. Still, direct influence of the party in agenda setting or decision-making should not be overestimated according to experts consulted in the process of this research.

Which organisations benefit most from emerging opportunities? Nonprofits with expertise in priority areas of government policies could best benefit from support and cooperation. Such areas currently include environmental education, ${ }^{23} \mathrm{Fu}$ (2018). Between Censorship and Commerce. A Perspective on Social Media in China. Presentation at Mercator Institute for China Studies, Berlin, 30 May 2018.

${ }^{24} \#$ Metoo in China: fledgling movement in universities fights censorship

https://www.theguardian.com/world/2018/apr/18/metoo-in-china-fledgling-movement-in-universiti es-fights-censorship 
health and pollution monitoring issues, but also extent to more abstract issues like climate change mitigation and adaptation or the promotion of sustainable development through research and educational activities.

Activities of nonprofits engaged in care for children, elderly and handicapped people are usually welcomed by government authorities. In projects with involvement of foreigners or foreign funding, e.g. nonprofits running orphanages with foreign funding support, government might monitor standards and activities very closely in particular if individuals or organisations are affiliated to religious congregations or communities.

Nonprofits reaching out to marginalised sections of society in the context of spreading awareness on issues of government concern would also be able to mobilise government support. The Chinese government realizes that building a welfare state and promoting ecological civilisation require collaborative efforts and the support of many social organisations with high levels of knowledge, motivation and good access to communities.

Contracting out of social services to nonprofits has significantly increased over the past years. Teets \& Jagusztyn (2016) pointed out that "outsourcing of social services intensified after the $12^{\text {th }}$ Five-Year Plan for National Economic and Social Development set a clear goal of increasing the amount of outsourced services (扩大购买服务 kuoda guomai fuwu) and referred to a diversified range of outsourced services." (pp. 69). Gao \& Tyson (2017: p. 1067) examined the administrative functions that have been carried out by social organizations (SOs) in China since 2013 and conclude that the drive for innovation and the delegation of functions to social organisations is motivated by efforts to improving governance and public service provision by streamlining administration and delegating power (Gao \& Tyson, 2017: p. 1067). According to talks with Chinese experts and along the line of the analysis presented by Thornton (2016) with reference to Lin (2013), China's political leadership is in the process of "accelerating the formation of a separation between state and society" (Thornton, 2016: pp. 137, Lin, 2013: p. 324) while promoting the role of the party in supervising and guiding social organisations. Tsinghua Professor Hu (2013) considers the rise of a Chinese people's society (renmin shehui，人民社会) led by the Chinese Communist Party inherently superior to the fragmented Western civil societies. Thornton (2016: p. 149) concludes that "few can disagree that the party has taken on a more ambitious agenda with respect to constructing a vibrant Chinese civil society through expanding its penetration into new civic organisations and social groups, particularly in urban areas."

Larger Chinese nonprofits could benefit from cooperation with government in the context of international cooperation. There are growing numbers of Chinese nonprofits attending major international conferences, e.g. The Conferences of the Parties of the United Nations Framework Convention on Climate Change or other conferences of the United Nations on environment and development. Organisations like Greenovation Hub or the Global Environmental Institute moni- 
tor China's outbound investment with regard to environmental standards and China's commitment to climate change mitigation. Both organisations would classify as middle-sized independent nonprofits in China. They engage in policy dialogue with government authorities and international organisations but receive large portions of their funds from abroad.

What about the opportunities and constraints for international organisations in China? Following a period of serious concerns in the context of the new law for the management of overseas NGOs, many of the major international NGOs managed to get their registration passed within one year and currently continue or even expand their activities in China. Some of them temporarily reduced their activities in the time around the registration procedure took place. For example, the German political foundations mentioned in talks that they had to reduce their activities for a while in the context of settling the registration problem even though they were already affiliated to renowned Chinese partner organisations.

The following section will comment on how international nonprofits (INGOs) developed their portfolio of activities in China, deal with new policies, laws and regulations and how they see their future in China in the light of the present changes and debates on shrinking spaces.

\subsection{Comments on the Activities and Prospects of INGO Is China}

\subsubsection{World Wide Fund for Nature, WWF China}

WWF, one of the largest environmental nonprofits, has been active in China since 1980, first from Switzerland and HongKong and from 1995/1996 with an office in Beijing. It was the first international conservation organisation invited to work in China. WWF China operates a website with detailed records of its activities and accomplishments. It refers to the long lasting cooperation between WWF and China's Ministry of Forestry and the joint development of a management plan for the species which was adopted by China's State Council in 1992. WWF was also active in providing training for China's wildlife conservationists. Over the years, WWF extended its activities and number of staff in China. Today, WWF works with many partners in conservation work and in promoting sustainable business practices. WWF was involved in launching China's pioneering low carbon demonstration cities, Baoding and Shanghai. WWF is engaged in raising awareness about conservation and sustainability issues and seeks to encourage the public and the private sector to take action through activities such as the 20 Ways to 20 percent energy saving initiative and Earth Hour, the world's largest climate change action campaign.

Today WWF has more than 130 staff, growing from 120 in 2010. Today there are no foreigners working directly at WWF China. In an interview, WWF stressed that it would continue its activities in full swing after the new law on management of foreign NGOs came into effect. The process of registration was strictly followed and required substantial efforts. Key partner of WWF is the Ministry of Forestry but today WWF also has today has to also liaison with the Ministry of Public Security. Reporting procedures would be slightly different 
and make some extra efforts necessary. WWF has to submit a work plan and present confirmation letters of partners. Memorandi of Understandings have to be signed with local governments. The creation of the new Ministry of Environment and Ecology is generally welcomed by WWF but would possibly create some administrative work to establish cooperation. WWF China does not receive funding from the Chinese government but mainly from its international network. The organisation is looking into opportunities of tapping potential financial resources in China and considers establishing a foundation under Chinese law. In sum, WWF China sees many opportunities to further expanding its work in China even though administrative charges are considered to be rather heavy.

\subsubsection{Save the Children}

Save the Children has been working in mainland China since the early 1980s. Its China website stresses collaboration with local communities, government and a variety of partners, including corporations and foundations, to ensure that all children, regardless of their background or abilities, receive quality services in China. SCF programmes works across five thematic sectors: child protection, child rights governance, education, health, and humanitarian response.

Save the Children emphasised its good cooperation with government at different levels. Government would appreciate the expertise of SCF and recognise its own limited capacities to reaching out to vulnerable children, in particular in poor provinces. In some provinces, e.g. Guizhou, there are only very few nonprofits working with children.

Scandals of abuse of children in kindergardens and alternative care institutions were reported in the press and made the Chinese public concerned and sensitive about child protection issues. The government has become more alert on the subject and extends cooperation to organisations with good reputation.

SCF did not have to interrupt its activities in China in the context of the new legislation on the management on foreign NGOs and got its new registration. Approval procedures were a bit cumbersome and SCF would have to cope with new reporting guidelines. The number of foreigners working for SCF in China would be more limited than before.

SCF emphasised the significant potential for fundraising in China, in particular in Beijing and Shanghai. SCF would look into opportunities to establishing a domestic foundation to strengthening its Chinese identity and to extending its fundraising activities in mainland China.

\subsubsection{The Asia Foundation}

The Asia Foundation (TAF) engages in policy dialogue and programme work on China's involvement and investment in Asia and at global scale but also addresses domestic issues. Civil society capacity building is one of the priority areas of TAF. It produced a manual for Chinese NGOs operating in Nepal in the field of humanitarian aid. Its support to local organisations extends to different 
fields, including domestic violence and child welfare. Like many international nonprofits, TAF is affiliated to the Chinese Friendship Society. TAF got its registration under the new law on 30 June 2017.

The organisations see new opportunities in the field of monitoring China's engagement in regional and global structures and activities, such as Asia Investment and Infrastructure Bank, BRICS Bank and One Belt one Road Initiative (OBOR).

\section{Conclusions: The China Case in the Context of Global Discourses}

This paper underscored the academic as well as social and practical significance of civil society and the work of nonprofits in China. Discourses that merely focus on restrictions for civil society, such as the "closed space" or "shrinking space" discourses, tend to overshadow the high degree of prevalence and relevance of civil society activities in China. Nonetheless, such discourses have certainly their merits in the context of policies and legislation that curtail the freedoms of certain civil society organisations, including those working on civil and political rights issues.

In the context of the dynamic and diverse private sector in China, the growing number of wealthy individuals and families and the enactment of the Charity Law in 2016 that provides new fundraising opportunities for nonprofits, it would be inappropriate to put China in the category of other authoritarian states that curtail the freedom of civil society in drastic ways. Unlike Russia where the number of nonprofits has not grown over the past years, the Chinese nonprofit sector still experiences growth in terms of number, capacities and outreach of organisations. Many nonprofits in China are run by passionate leaders exhibiting features typical to civil society organisations, such as charismatic leadership, public benefit orientation, support by volunteers, nonprofit status and a significant autonomy in agenda setting.

The Chinese government extends growing support to nonprofits that work on issues such as pollution monitoring, environmental and health education, child protection, support to disabled persons and elderly care. Fisher et al. (2018: p. 66) conclude in their case study on disability employment in China that "this decade has seen an increasing number of non-governmental actors such as NGOs, social entrepreneurs, digital start-ups, and e-commerce entrepreneurs by and for disabled people facilitating the expansion of disability employment.

While government administration steps up support for nonprofits and tends to recede from direct implementation of the growing number of social welfare activities and gives way to stronger involvement of nonprofits, the Chinese Communist Party (CCP) has expanded its supervision, control but also interaction with the still bourgeoning nonprofit sector.

Chinese nonprofits mobilise growing funding support from the corporate sector. Furthermore, major online charity platforms, e.g. Tencent Charity, and 
innovative fund raising features are indications that sign bode well for the further growth of the sector. We also see an emerging engagement of Chinese NGOs in the provision of humanitarian aid to people affected by disasters in other countries.

After a period of heightened concern of international NGOs in the context of new legislation, more pragmatic attitudes are setting in as most of the larger international NGOs managed to register under the new law on the Administration of Overseas NGOs. Many nonprofits in China, including some international NGOs, see their scope of action and influence expanded rather than shrunk, in particular in the context of China's ambitions for sustainable economic and social development and its fight against rural poverty, air and water pollution. The Chinese Government is contracting out more services to NGOs but also tightens political supervision and rewards affiliations to the Chinese Communist Party (CCP).

\section{Funding}

The publication of this paper has been financially supported by the Open Access Publication Fund of Freie Universität Berlin.

\section{Conflicts of Interest}

The authors declare no conflicts of interest regarding the publication of this paper.

\section{References}

Alscher, M., \& Priller, E. (2017). The Changing Social Fabric. In Maecenata Institut für Philanthropie und Zivilgesellschaft (Ed.), The Space for Civil Society: Shrinking? Growing? Changing (pp. 11-15)? Berlin. http://nbn-resolving.de/urn:nbn:de:0168-ssoar-54028-9

Anheier, H., Glasius, M., \& Kaldor, M. (2001). Global Civil Society 2001. New York: Oxford.

Appe, S., \& Pallas, C. L. (2018). Aid Reduction and Local Civil Society; Causes, Comparisons and Consequences. Voluntas: International Journal of Voluntary and Nonprofit Organizations, 29, 245-255. https://doi.org/10.1007/s11266-017-9846-0

Ashwin, K., \& Stratford, T. (2016). China Implements New Charity Law. Global Policy Watch.

Bertelsmann Transformation Index (2018). China Country Report. https://www.bti-project.org/en/reports/country-reports/detail/itc/CHN/

Bertelsmann Transformation Index (2018). https://www.bti-project.org

Brook, T. (1997). Auto-Organization in Chinese Society. In T. Brook, \& B. M. Frolic (Eds.), Civil Society in China (pp. 19-45). New York, London: M.E. Sharpe.

Carothers, T., \& Brechenmacher, S. (2014). Closing Space. Democracy and Human Rights Support under Fire. Carnegie Endowment for International Peace.

China Development Brief (2015). A Simple Guide to the Overseas NGO Law. Beijing: China Development Brief.

China File (2017). The China NGO Project. Fact Sheet on China's Foreign NGO Law. 
http://www.chinafile.com/ngo/latest/fact-sheet-chinas-foreign-ngo-law

CIVICUS (2017a). Civil Society Monitor. https://monitor.civicus.org/

CIVICUS (2017b). Monitor. Tracking Civic Space.

https://monitor.civicus.org/country/china/

Council on Foundations (2017). China. https://www.cof.org/content/china

Ding, Y. (2008). Third Sector Governance in China: Structure, Process and Relationships. In S. Hasan, \& J. Onyx (Eds.), Comparative Third Sector Governance in Asia. Structure, Process, and Political Economy (pp. 212-213). New York: Springer. https://doi.org/10.1007/978-0-387-75567-0_12

European Foundation Centre (2017). Announcement of the above Mentioned Symposium on the Changing Space for Civil Society. http://www.efc.be/event/the-changing-space-for-civil-society/

European Parliament (2017). Shrinking Space for Civil Society. Brussels: The EU Response.

Fioramonti, L. (2012). Methodological Note on the CIVICUS' Civil Society Enabling Environment Index.

https://www.civicus.org/downloads/Methodological\%20note\%20on\%20the\%20CIVIC US\%20Civil\%20Society\%20Enabling\%20Environment\%20Index.pdf

Fisher, K., Yu, H., Li, B., \& Goggin, G. (2018). Disability Employment in China: Empowerment through Digital Solutions. Berlin: Mercator Institute for China Studies.

Freedom House (2018). Freedom in the World. https://freedomhouse.org https://freedomhouse.org/report/freedom-world/2018/china

Frolic, B. M. (1997). State-Led Civil Society. In T. Brook, \& B. M. Frolic (Eds.), Civil Society in China. New York, NY, London: M.E. Sharpe.

Frolic, B. M. (1997). State-Led Civil Society. In T. Brook, \& B. M. Frolic (Eds.), Civil Society in China (pp. 46-67).

Fu, K.-W. (2018). Between Censorship and Commerce. A Perspective on Social Media in China. Berlin: Mercator Institute for China Studies.

Gao, B., \& Xia, X. (2016). The Emergence of an Autonomous Social Sector in China. In H. Reza, \& J. Hsu (Eds.), NGO Governance and Management in China (pp. 29-44). London \& New York, NY: Routledge.

Gao, H., \& Tyson, A. (2017). Administrative Reform and the Transfer of Authority to Social Organizations in China. The China Quarterly, 232, 1050-1069.

Gasemyr, H.-J. (2018). Welfare and Service-Provision for the New Era: Do Chinese People Welcome Non-State Actors?

GIGA (2017). Shrinking Spaces for NGOs. How to Deal with the Rise of Authoritarian Practices?

https://www.giga-hamburg.de/de/event/shrinking-spaces-for-ngos-how-to-deal-with-t he-rise-of-authoritarian-practices

Gitter, D. (2016). Why China Both Loves and Fears the Rule of Law. https://thediplomat.com/2016/06/why-china-both-loves-and-fears-the-rule-of-law/

Gransow, B. (2004). NGOs in Chinas Armutsbekämpfung-Globalisierung von innen? Peripherie, 96, 428-457.

Heilmann, S., \& Stepan, M. (2016). China's Core Executive. Leadership Styles, Structures and Processes under Xi Jinping. Berlin: Mercator Institute for China Studies.

Hildebrandt, T. (2016). From NGO to Enterprise: The Political Economy of Activist Adaptation in China. In R. Hasmath, \& J. Y. J. Hsu (Eds.), NGO Governance and 
Management in China (pp. 121-137). London \& New York, NY: Routledge.

Hildermeier, M., Kocka, K., \& Conrad, C. (2000). Europäische Zivilgesellschaft in Ost und West. Begriff, Geschichte, Chancen, Frankfurt a. M.

$\mathrm{Hu}$, A. (2013). Renmin Shehui Weihe Youyu Gongmin Shehui? Why People's Society Is Superior to Civil Society. Renmin Ribao Haiwai Ban.

Huang, S. (2013). Building China's Nascent Civil Society: The Roles of Nongovernmental Organizations. American Anthropologist, 115, 499-501.

https://doi.org/10.1111/aman.12032

Hummel, S., \& Kreutzer, P. (2017). The Changing Space for Civil Society: Symposium on 17 October in Berlin. http://nbnresolving.de/urn:nbn:de:0168-ssoar-55079-0

Jia, X. (2018). Legitimacy and Space: An Evaluation on China's Overseas NGO Law, Presentation at ISTR World Conference. Amsterdam.

Kennedy, M., \& Phillips, T. (2017). Cambridge University Press Backs down over China Censorships.

https://www.theguardian.com/education/2017/aug/21/cambridge-university-press-to-b ack-down-over-china-censorship

Kuhn, B. (2005/2009). Development Politics between Market and State. Potentials and Limitations of Civil Society Organisations. Frankfurt, New York, NY: Campus Publishers.

Kuhn, B. (2005/2009). Development Politics between Market and State. Potentials and Limitations of Civil Society Organisations. Frankfurt, New York (2005), Beijing (2009).

Kuhn, B. (2011). Use and Appreciation of BTI and FHI. Journal of Political Science, 21, 577-602.

Lang, B. (2018). Shrinking Civic Space: How It Plays out in Asia and How We Should Deal with It. Comments provides at GIGA Talk and Lectures. Berlin.

Levy, K. (2018). Boon or Bane? The Impact of Two Recent Laws on Civic Organisations and Their Work in the P.R. China.

Lin, R. (2013). Securities and Future of China (pp. 324-325).

Ma, S.-Y. (1994). The Chinese Discourse on Civil Society. China Quarterly, No. 137, 180-193. https://doi.org/10.1017/S030574100003410X

Ministry of Civil Affairs (2018). Statistics of Social Services in the Second Quarter of 2018. http://www.mca.gov.cn/article/sj/tjjb/sjsj/2018/20180608021510.html

Saich, T. (2018). Answers to Interview Questions by the China NGO Project under the Heading "Chinese Civil Society in 2018 What's Ahead"? Discussion at Asia Society in New York, 29 January 2018 Hosted by ChinaFile and the National Committee on U.S.-China Relations.

Salomon, L., Anheier, H., List, R., Toepler, S., \& Sokolowski (1999). Global Civil Society. Dimensions of the Nonprofit Sector. Baltimore, MD: Johns Hopkins Center for Civil Society Studies.

Shen, Y. (2018). The Effect of Government Funding on NGOs's Additional Resource-Raising Activities . Presentation at ISTR World Conference. Amsterdam.

Sidel, M. (2018). More Third Sector, Less Civil Society. Presentation at ISTR World Conference. Amsterdam.

Simon, K. (2013). Civil Society in China. The Legal Framework from Ancient Times to the "New Reform Era". Oxford: Oxford University Press. https://doi.org/10.1093/acprof:oso/9780199765898.001.0001

Strachwitz, R. (2017). Shrinking or Changing? In Maecenata Institut für Philanthropie 
und Zivilgesellschaft (Ed.), The Space for Civil Society: Shrinking? Growing? Changing (pp. 5-10)? Berlin.

Teets, J., \& Jagusztyn, M. (2016). The Evolution of a Collaborative Governance Model. Social Service Outsourcing to Civil Society Organisations in China. In H. Reza, \& J. Y. J. Hsu (Eds.), NGO Governance and Management in China (pp. 68-88). London \& New York, NY: Routledge.

The Guardian (2018). \#Metoo in China: Fledgling Movement in Universities Fights Censorship.

https://www.theguardian.com/world/2018/apr/18/metoo-in-china-fledgling-movement -in-universities-fights-censorship

Thornton, P. (2016). Experimenting with Party-Led “People's Society: Four Regional Models". In R. Hasmath, \& Y. J. H. Jennifer (Eds.), NGO Governance and Management in China (pp. 137-150). London \& New York, NY: Routledge.

Unmuessig, B. (2016). Civil Society under Pressure-Shrinking-Closing-No Space.

Wang, M. (2011). Emerging Civil Society in China, 1978-2008. Amsterdam: Brill. https://doi.org/10.1163/ej.9789004188136.i-397

Wolff, J., \& Poppe, A. E. (2015). From Closing Space to Contested Space (Report 137). Frankfurt: Peace Research Institute. https://www.hsfk.de/fileadmin/HSFK/hsfk_downloads/prif137.pdf

World Justice Project, Rule of Law Index (2018). China. http://data.worldjusticeproject.org/\#/groups/CHN

Xinhua (2016a). Xinhua Insight: Charity Law to Smooth China's Last-Mile Drive to 2020 Targets.

Xinhua (2016b). Xinhua Insight: NPC Hopes Charity Law Can Help Poverty Fight.

Zhu, J. (2018). Rethinking the Local-Government-NPOs Relations under the Authoritarian Regime.

Zhu, J. (2018). Rethinking the Local-Government-NPOs Relations under the Authoritarian Regime. Presentation at the ISTR World Conference. Amsterdam.

Zhu, Y. (2015). Dependent Interdependence: The Complicated Dance of Government-Nonprofit Relations in China. Voluntas. International Journal of Voluntary and Nonprofit Organizations, No. 26, 2395-2423. 